\title{
Effects of Biodiesel Saturation Degrees on NOx Emission and FTIR Spectroscopy
}

\author{
Mohd Fareez Edzuan Bin Abdullah ${ }^{1}$, Nadzirah Binti Madzrol ${ }^{2}$ and \\ Rolf Willa Anak Patrick Sandin ${ }^{3}$ \\ ${ }^{1,2,3}$ Fakulti Kejuruteraan, Universiti Malaysia Sarawak, Kota Samarahan, Malaysia. \\ ${ }^{1}$ Email: amfedzuan@feng.unimas.my, ${ }^{2}$ Email:nadz_irah92@yahoo.com, \\ ${ }^{3}$ Email: willarop@gmail.com
}

\begin{abstract}
The Fourier Transform Infrared (FTIR) spectroscopic characteristics of biodiesel produced from vegetable oils with different saturation degree was investigated in this study. Unsaturation degree, usually determined by the Iodine Value (IV) indicates the sum of double bonds, triple bonds and/or rings. In this work, biodiesels were produced by canola oil, palm oil and coconut oil that have saturation degree of $7.0 \mathrm{wt} \% .45 .6 \mathrm{wt} \%$ and $81.5 \mathrm{wt} \%$, respectively. Biodiesel blends of B10, B15 and $B 20$ were tested in a direct injection diesel engine and the NOx emissions were measured with a flue gas analyser. The NOx emission was increased in all biodiesel cases, where the NOx emission seems to be proportional with the biodiesel unsaturation degree. The FTIR spectroscopy of each biodiesel was analysed with FTIR spectrometer. Each biodiesel produced different FTIR spectroscopy characteristics and the double bond of $C=O$ was the most abundant in highly unsaturated canola oil methyl ester which suggested that FTIR spectroscopy can be suitable to analyse biodiesel characteristics.
\end{abstract}

Keywords: FTIR spectrometer, spectroscopy analysis, biodiesel, saturation degree, NOx emission

\section{Introduction}

Diesel engine have proved to be an indispensable technology despite of constant concern regarding its harmful exhaust pollutant. Numerous efforts have been carried out in the past two decades to reduce diesel engine pollutant in order to meet ever stringent regulation requirements. Recent technology to simultaneously reduce particulate matter (PM) and nitrogen oxides (NOx) emission including homogenous-charged compression ignition (HCCI) engine and exhaust gas recirculation (EGR) system are being developed with promising results [1, 2]. However, conventional diesel engine needs to be replaced or undergone extensive alterations to adopt those strategies.

Due to the limited petroleum fuel supply and environmental concerns, researches on sustainable alternative fuels are gaining attraction. Diesel engine was originally envisioned to run with a pure vegetables oil but due to its much higher viscosity than petroleum based diesel fuel, it cannot be burned properly and may damage modern diesel engine. Transesterification process converts vegetable oil to a less viscous fatty acids methyl ester (FAME) famously known as biodiesel nowadays. Biodiesel is particularly a standout alternative fuel because it can be used with the conventional diesel engine without any major modification. It is biodegradable, oxygenated and low toxicity fuel that can be derived from various feedstocks such as vegetable oils, woods and even

Manuscript History:

Received 15 September, 2015, Revised 7 March, 2016, Accepted 22 March, 2016, Published 31 March, 2016

e-ISSN 2289-7771

Copyright (C) 2016 JASPE

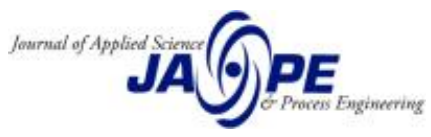


animal fats/ oil waste. In technical aspects biodiesel inherent better lubricity, superior flash point, lower sulphur content and nonaromatic as compared to the petroleum diesel [3].

Biodiesel have been widely reported to reduce PM or black smoke emission when it is used as diesel blends. Researchers suggest that the reduction of the PM emission is mainly due to oxygen content in biodiesel (approximately 10\%) which enhances air-fuel mixing process thus promotes complete combustion $[4,5,6]$. Results from Fourier transform infrared spectrometer (FTIR) confirmed that castor biodiesel contained oxygen functional group such as ester $\mathrm{C}-\mathrm{O}$ bond at $1000 \mathrm{~cm}^{-}$ ${ }^{1}$ to $1300 \mathrm{~cm}^{-1}$ and ester $\mathrm{C}=\mathrm{O}$ at $1735 \mathrm{~cm}^{-1}$ to $1750 \mathrm{~cm}^{-1}$, whereas conventional diesel showed no sign of oxygen functional group [6]. It was reported that smoke emission was reduced when biodiesels were used in conventional diesel engine and in constant volume combustion chamber $[7,8]$.

In contempt of FAME fuel advantages over petroleum fuel, there are still some resistance for its prompt adaptation. The major reason may be due to lack of knowledge on biodiesel disadvantages, for example increase of fuel consumption, reduce of engine power, higher cetane number and higher NOx emission. Biodiesel fuelled diesel engine showed a phenomena of NOx emission accretion known as the "biodiesel NOx effect". Several theories are associated with this phenomena namely high flame temperature due to excess oxygen content in biodiesel, higher combustion residence time due to biodiesel higher bulk modulus and higher prompt NOx production that is sensitive to fuel chemistry as in unsaturated FAME $[9,10,11,12,13]$. Endless argument have been discussed as the biodiesel NOx effect seems to be impossible to be explained by a parameter only e.g. oxygen content, cetane number. Even though numerous researches have been conducted to study biodiesel effects on engine performances and emissions, rapid emergence of technology, lack of proper standardizations methods and frequent regulation changes make it challenging for the researchers to supply sufficient reliable output $[14,15,16,17]$.

Diesel combustion occurs at elevated temperature above $1800 \mathrm{~K}$ thus thermal NOx mechanism dominates total NOx emission compared to prompt NOx and fuel NOx [13, 14]. It was noticed that different saturation degree of biodiesels produce different amount of NOx formation even though their oxygen contents are approximately equal. Knothe et al. argued that prompt NOx may be significant in biodiesel cases as the unsaturation in methyl esters lead to formation of various intermediate combustion products that are responsible for NOx formation [18, 19]. Thus the chemical structure characteristics of fatty acids methyl esters with different saturation degree are of great interest as it can provide additional knowledge regarding the biodiesel effects on combustion. The FTIR spectroscopy has a potential in analysing biodiesel chemical characteristics based on their functional group especially at the low frequency finger print region as compared to time consuming and expensive gas or liquid chromatograph analysis. Ndana et al. noticed that castor, rubber and jatropha biodiesels might have different FTIR spectroscopy properties [20]

In this study, biodiesels are produced from canola oil, palm oil and coconut oil and heir blends are used to run a diesel test rig. Exhaust tailpipe NOx emissions are measured and compared to conventional diesel fuel. FTIR spectrometer is used to study the spectroscopy properties of the biodiesels.

\section{Methods and Materials}

\subsection{Production of biodiesels}

Biodiesel is mainly produced by transesterification process where vegetable oils or animal fats being reacted with a short chain alcohol to form methyl ester (biodiesel) and glycerol as by product. In this study, domestic purpose virgin canola, palm and coconut oils that was chosen based on their saturation degree of $7.0 \mathrm{wt} \% .45 .6 \mathrm{wt} \%$ and $81.5 \mathrm{wt} \%$, respectively. Base-catalysed transesterification process was conducted by mixing $2.8 \mathrm{~g}$ potassium hydroxide $(\mathrm{KOH})$ with $100 \mathrm{ml}$ methanol. $\mathrm{KOH}-$ methanol mixture was heated up to $60^{\circ} \mathrm{C}$ before $400 \mathrm{ml}$ of vegetable oil was added. The mixture was 
then stirred with a magnetic stirrer at constant temperature for 10 minutes. After transesterification process was completed, the mixture was allowed to settle for 2 days before pouring it into separatory funnel. Higher density glycerol and other by products settled at lower layer were drained down. Warm washing process was conducted for several times to remove any residuals and impurities in biodiesel. The biodiesel was then heated up to $100^{\circ} \mathrm{C}$ to remove any remaining water before being filtered and sealed in a container. Biodiesel and petroleum diesel fuel were blended to B10, B15 and B20 based on biodiesel weight percentage of $10 \mathrm{wt} \%, 15 \mathrm{wt} \%$ and $20 \mathrm{wt} \%$, respectively.

\subsection{Fuel Properties}

Fuel testing were carried out by Parr 6400 Automatic Isoperibol Calorimeter to compare the heating value properties of coconut oil methyl ester (CoOME), palm oil methyl ester (POME), canola oil methyl ester (CaOME) and conventional diesel fuel. Due to measurement device limitation, some other important properties of the fuels were taken from other literature as shown in Table 1 [13]. Shimadzu IRAffinity-1 FTIR spectrometer was used to identify functional groups for each biodiesels, petroleum diesel and virgin vegetable oils in this study.

\subsection{Engine tests}

The fuel blends were tested in a Kubota RK95-1-NB-RDK single cylinder compression ignition diesel engine in idling condition as shown in Figure 1 and Table 2. Testo 350-XL flue gas analyser was used to measure the tailpipe exhaust emission for several times within 10 minutes.

\section{Results and Discussions}

Calorific value can be an important indicator for biodiesel quality as it measures amount of energy contained. Typical conventional diesel fuel calorific value is approximately $44.80 \mathrm{MJ} / \mathrm{kg}$ while biodiesels have lesser due to its 10-12\% oxygen content, which leads to proportionally lower energy density. In this study, the results are in good agreement with the previous literature as the amount of the biodiesels calorific values range from $37.00 \mathrm{MJ} / \mathrm{kg}$ to $39.80 \mathrm{MJ} / \mathrm{kg}$ as shown in Table 1. From Pearson correlation coefficients result, calorific value might have a moderate relationship with unsaturation degree but correlate rather well with the oxygen content [21].

Figure 2 shows the NOx emissions results for B10, B15 and B20 blends for coconut oil methyl ester (CoOME), palm oil methyl ester (POME) and canola oil methyl ester (CaOME) compared to the conventional diesel fuel. The results showed the biodiesel NOx effect trend where all blends produced more NOx than conventional diesel fuel where the NOx emissions were increased as the biofuels amount were increased from $10 \mathrm{wt} \%$ to $20 \mathrm{wt} \%$. It was reported that the oxygen content in biodiesel promotes complete combustion thus will increase combustion temperature as well as the NOx emission [17]. However Monyem et al. argued that the adiabatic flame temperature of biodiesel does not increase as it contains lower calorific value than conventional diesel fuel [16].

Figure 3 shows the NOx emissions results for B20 blends for canola, palm and coconut methyl ester. Generally, major portion of NOx emission in diesel combustion was produced via thermal NOx mechanism, however it was interesting to observe that the NOx emission increased as the unsaturation degree of biodiesel was increased [14]. It were claimed elsewhere that the prompt NOx mechanism is promoted by double bonds contained particularly in less saturated methyl ester due to free radicals formation at the flame front [18]. Excess oxygen availability might indicates that higher flame temperature might leads to higher thermal NOx, but prompt NOx could be significant for the total NOx in unsaturated biodiesel cases. 
FTIR spectrometer utilises the phenomenon where particular chemical bond can be vibrated by particular infra-red (IR) radiation wavelength or frequency. As the IR radiation is passed through an organic compound, only certain frequencies are absorbed by matching chemical bonds. A standard Fourier transform algorithm is used to convert the strength of absorption as a function of the frequency. A FTIR spectrum region can be divided into the functional group region where the functional groups are fairly easy to identify and the fingerprint region that is unique for each chemical compound but require extensive knowledge to classify the functional groups. FTIR spectroscopy method has a potential to analyse the characteristics and quality of biodiesel at a low cost, less time consuming and non-destructive [22].

The FTIR functional group frequencies of CaOME, POME and CoOME are presented in Table 3, 4 and 5, respectively. FTIR spectroscopy at the fingerprint region (below $1500 \mathrm{~cm}^{-1}$ ) showed a unique bond detection for each biodiesel tested while the detection regions were almost similar at the functional group region (above $1500 \mathrm{~cm}^{-1}$ ). Biodiesel water contamination indicator alcohol group (O$\mathrm{H}$ bonds) was present in the CaOME and POME at approximately $3400 \mathrm{~cm}^{-1}$ but was absent in CoOME. Ismail et al. compared IR spectrum of the conventional diesel and castor biodiesel where the oxygen group was only present in the castor biodiesel FTIR spectrum (ester $\mathrm{C}-\mathrm{O}$ and $\mathrm{C}=\mathrm{O}$ bond) and a broad region nearby $3400 \mathrm{~cm}^{-1}$ region may indicated biodiesel water contamination [6]. It can be observed that $\mathrm{CaOME}$ FTIR spectroscopy was abundant with double bonds $\mathrm{C}=\mathrm{O}$ which correlate well with its high unsaturation degree. This results suggested the possibility to determine biodiesel's feedstock and characteristics by FTIR spectroscopy analysis.

Table 1. Properties of various methyl esters of fatty acids

\begin{tabular}{|l|c|c|c|c|c|}
\hline FAME & $\begin{array}{c}\text { Saturation degree } \\
{[\mathbf{w t} \%]}\end{array}$ & $\begin{array}{c}\text { Iodine } \\
\text { value }\end{array}$ & $\begin{array}{c}\text { Cetane } \\
\text { number }\end{array}$ & $\begin{array}{c}\text { Kinematic viscosity } \\
\text { at } \mathbf{4 0}^{\circ} \mathbf{C}\left[\mathbf{m m}^{\mathbf{2}} / \mathbf{s}\right]\end{array}$ & $\begin{array}{c}\text { Calorific value } \\
{[\mathbf{M J} / \mathbf{k g}]}\end{array}$ \\
\hline Canola & 7.0 & $110-120$ & 51.6 & 4.020 & 38.59 \\
\hline Palm & 45.6 & $44-58$ & 56.2 & 4.958 & 39.80 \\
\hline Coconut & 81.5 & $8-10$ & 68.0 & 2.726 & 37.00 \\
\hline
\end{tabular}

Table 2. Diesel engine specifications

\begin{tabular}{|l|c|}
\hline Items & Specifications \\
\hline Manufacturer & Kubota Engine \\
\hline Model & RK95-1-NB-RDK \\
\hline Injection type & Direct injection \\
\hline Air intake & Naturally aspirated \\
\hline Bore $\times$ stroke $[\mathrm{mm}]$ & $86 \times 84$ \\
\hline Displacement $[\mathrm{cc}]$ & 487 \\
\hline Maximum output $[\mathrm{kW}]$ & $7.09(2400 \mathrm{rpm})$ \\
\hline Continuous output $[\mathrm{kW}]$ & $5.97(2200 \mathrm{rpm})$ \\
\hline Maximum torque $[\mathrm{kgfm}]$ & $3.08(1800 \mathrm{rpm})$ \\
\hline
\end{tabular}




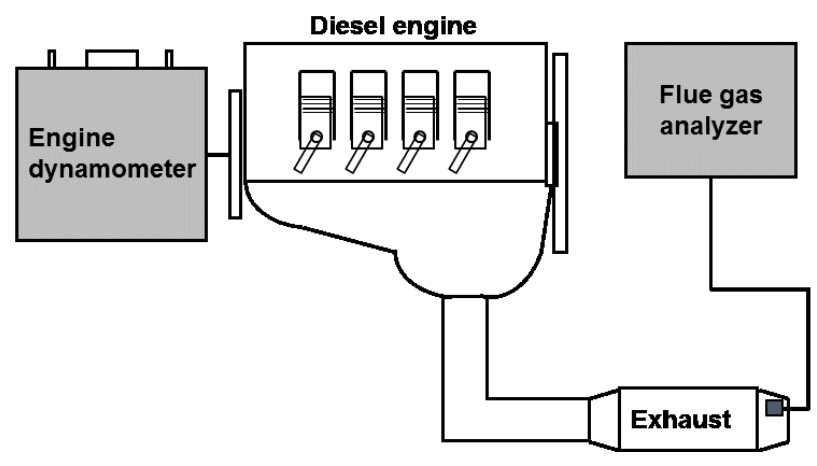

Figure 1. Experimental setup for diesel engine test rig

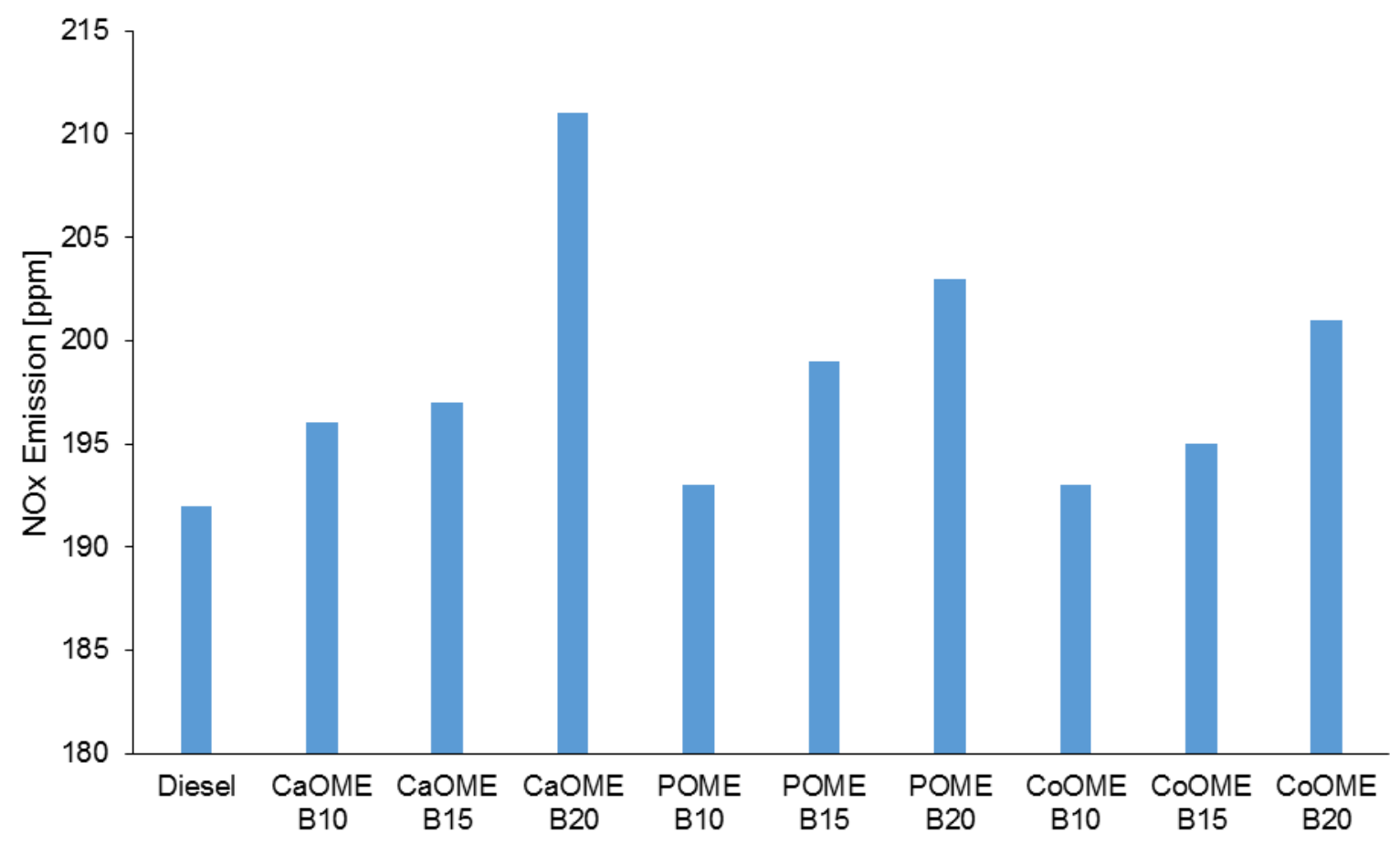

Figure 2. NOx emission of biodiesel blends and conventional diesel 


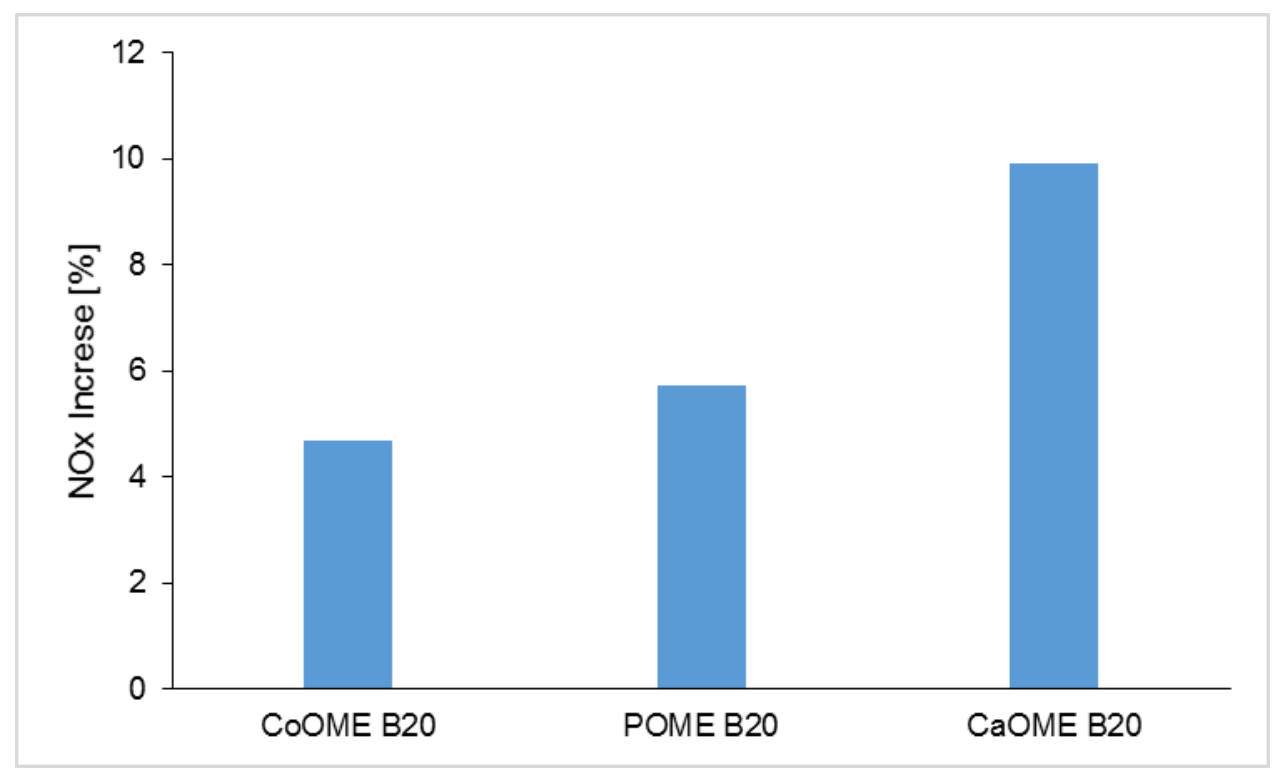

Figure 3. NOx emission increase percentage of biodiesel B20 blends compared to conventional diesel

Table 3. FTIR functional group frequencies of CaOME

\begin{tabular}{|l|c|c|c|}
\hline No & Wave number $\left[\mathbf{c m}^{-\mathbf{1}}\right]$ & Vibration mode & Bond \\
\hline 1 & 700.16 & Rocking & $\mathrm{C}-\mathrm{H}$ \\
\hline 2 & 721.38 & Rocking & $\mathrm{C}-\mathrm{H}$ \\
\hline 3 & 1165.00 & Bending & $\mathrm{C}-\mathrm{C}, \mathrm{C}-\mathrm{O}$ \\
\hline 4 & 1188.15 & Bending & $\mathrm{C}-\mathrm{C}, \mathrm{C}-\mathrm{O}$ \\
\hline 5 & 1454.33 & Bending & $\mathrm{C}-\mathrm{H}, \mathrm{O}-\mathrm{H}$ \\
\hline 6 & 1647.21 & Bending & $\mathrm{C}=\mathrm{O}$ \\
\hline 7 & 1737.86 & Bending & $\mathrm{C}=\mathrm{O}$ \\
\hline 8 & 1739.79 & Bending & $\mathrm{C}=\mathrm{O}$ \\
\hline 9 & 2858.65 & Stretch & $\mathrm{C}-\mathrm{H}$ \\
\hline 10 & 2906.73 & Stretch & $\mathrm{C}-\mathrm{H}$ \\
\hline 11 & 2924.05 & Stretch & $\mathrm{C}-\mathrm{H}$ \\
\hline 12 & 3570.24 & Stretch & $\mathrm{O}-\mathrm{H}$ \\
\hline
\end{tabular}


Table 4. FTIR functional group frequencies of POME

\begin{tabular}{|l|c|c|c|}
\hline No & Wave number $\left[\mathbf{c m}^{-1}\right]$ & Vibration mode & Bond \\
\hline 1 & 719.45 & Rocking & $\mathrm{C}-\mathrm{H}$ \\
\hline 2 & 721.38 & Rocking & $\mathrm{C}-\mathrm{H}$ \\
\hline 3 & 862.18 & Rocking & $\mathrm{C}-\mathrm{H}$ \\
\hline 4 & 1029.99 & Bending & $\mathrm{C}-\mathrm{C}, \mathrm{C}-\mathrm{O}$ \\
\hline 5 & 1172.72 & Bending & $\mathrm{C}-\mathrm{C}, \mathrm{C}-\mathrm{O}$ \\
\hline 6 & 1190.08 & Bending & $\mathrm{C}-\mathrm{C}, \mathrm{C}-\mathrm{O}$ \\
\hline 7 & 1446.61 & Bending & $\mathrm{C}-\mathrm{H}, \mathrm{O}-\mathrm{H}$ \\
\hline 8 & 1452.40 & Bending & $\mathrm{C}-\mathrm{H}, \mathrm{O}-\mathrm{H}$ \\
\hline 9 & 1735.93 & Bending & $\mathrm{C}=\mathrm{O}$ \\
\hline 10 & 1737.86 & Bending & $\mathrm{C}=\mathrm{O}$ \\
\hline 11 & 2904.80 & Stretch & $\mathrm{C}-\mathrm{H}$ \\
\hline 12 & 2924.09 & Stretch & $\mathrm{C}-\mathrm{H}$ \\
\hline 13 & 3223.05 & Stretch & $\mathrm{O}-\mathrm{H}$ \\
\hline 14 & 3383.14 & Stretch & $\mathrm{O}-\mathrm{H}$ \\
\hline
\end{tabular}

Table 5. FTIR functional group frequencies of CoOME

\begin{tabular}{|l|c|c|c|}
\hline No & Wave number $\left[\mathbf{c m}^{-1}\right]$ & Vibration mode & Bond \\
\hline 1 & 603.72 & Rocking & $\mathrm{C}-\mathrm{H}$ \\
\hline 2 & 682.80 & Rocking & $\mathrm{C}-\mathrm{H}$ \\
\hline 3 & 698.23 & Rocking & $\mathrm{C}-\mathrm{H}$ \\
\hline 4 & 1176.58 & Bending & $\mathrm{C}-\mathrm{C}, \mathrm{C}-\mathrm{O}$ \\
\hline 5 & 1192.01 & Bending & $\mathrm{C}-\mathrm{C}, \mathrm{C}-\mathrm{O}$ \\
\hline 6 & 1336.67 & Bending & $\mathrm{C}-\mathrm{H}, \mathrm{O}-\mathrm{H}$ \\
\hline 7 & 1492.90 & Bending & $\mathrm{C}-\mathrm{H}, \mathrm{O}-\mathrm{H}$ \\
\hline 8 & 1735.93 & Bending & $\mathrm{C}=\mathrm{O}$ \\
\hline 9 & 1737.86 & Bending & $\mathrm{C}=\mathrm{O}$ \\
\hline 10 & 2906.73 & Stretch & $\mathrm{C}-\mathrm{H}$ \\
\hline 11 & 2908.65 & Stretch & $\mathrm{C}-\mathrm{H}$ \\
\hline
\end{tabular}

\section{Conclusions}

FTIR spectrometer was used to study the spectroscopy characteristics of biodiesels with different unsaturation degree. Fatty acid methyl ester produced from canola oil, palm oil and coconut oil were tested with bomb calorimeter, flue gas analyser and FTIR spectrometer. NOx emission increased proportionally with biodiesel amount in the blend and the NOx emission seems to increase as the biodiesel unsaturation degree was increased. From FTIR spectroscopy analysis, double bond of $\mathrm{C}=\mathrm{O}$ was most abundant in highly unsaturated canola oil methyl ester compared to more saturated palm oil methyl ester and coconut oil methyl ester. FTIR spectroscopy might promises a low cost, less time consuming and non-destructive analysis method in determining biodiesel characteristics and quality. 


\section{Acknowledgements}

This research is supported by the RAGS (Dana Pembudayaan Penyelidikan) Grant under the Ministry of Education Malaysia. The authors are grateful to the Faculty of Engineering, UNIMAS and technical staff of Departmental of Mechanical \& Manufacturing Engineering and Departmental of Chemical Engineering \& Energy Sustainability for the facilities and technical supports.

\section{References}

[1] Salvador M. A., Daniel L. F., Joel M., Smith J. R., Robert D., Michael A. and James G. (2001). HCCI Combustion: Analysis and Experiments, SAE International Government/ Industry Meeting, Vol. 1, No. 2077.

[2] Kim D. S. and Lee C. S. (2006). Improved Emission Characteristics of HCCI Engine by Various Premixed Fuels and Cooled EGR, Fuel, Vol. 85, 695-704.

[3] Joana M. D., Maria C. M. A and Manuel F. A. (2008). Mixtures of Vegetable Oils and Animal Fat for Biodiesel Production: Influence on Product Composition and Quality, Energy Fuels, Vol. 2, No. 6, 38893893.

[4] Ozsezen A. N., Canakci M., Turkcan A. and Sayin C. (2009) Performace and Combustion Characteristics of a DI diesel Engine Fuelled with Waste Palm Oil and Canola Methyl Esters, Fuel, Vol. 88, 629-636.

[5] Park H., Kim H. and Choi B. (2009) Emission Characteristics of Exhaust Gases and Nanoparticles from a Diesel Engine with Biodiesel-Diesel Blended Fuel (BD20), Journal of Mechanical Science and Technology, Vol. 23, 2555-2564.

[6] Ismail S., Abu S. A., Rezaur R. and Sinin H. (2014) Biodiesel Production from Castor Oil and Its Application in Diesel Engine, ASEAN Journal on Science and Technology for Development, Vol. 31, No. 2, 91-101.

[7] Ganakci M. and Van Gerpen J. H. (2003) Comparison of Engine Performance and Emissions for Petroleum Diesel Fuel, Yellow Grease Biodiesel, and Soybean Oil Biodiesel, American Society of Agricultural Engineers, Vol. 46, No. 4, 937-944.

[8] Aizawa T., Abdullah M. F. E., Inoue A., Ishidzuka Y., Taki N. and Kosaka, H. (2012). Aromatic Additive Effects on Soot Formation in a Fischer-Tropsch Diesel (FTD) Spray Flame via Laser Spectroscopy, Proceedings of the 8th COMODIA, 275-280.

[9] Pham P. X., Wang H., Brown R. J. and Masri A. R. (2013) Engine Performance Characteristics for Biodiesels of Different Degrees of Saturation and Carbon Chain Lengths, SAE International Journal of Fuels and Lubricants, Vol. 6, No. 1, 188-198.

[10] Abdullah M. F. E., Sulaiman M. H. and Abdul Majid N. A. (2014) NOx Emission of Diesel Fuel Blended with Different Saturation Degrees of Biofuel and with Oxygenator, Applied Mechanics and Materials, Vol. 660, 397-401.

[11] Lapuerta M, Armas O, Ballesteros R. and Fernandez J. (2005) Diesel Emissions from Biofuels Derived from Spanish Potential Vegetable Oils, Fuel, Vol. 84, 773-780.

[12] Lapuerta M, Armas O, and Fernandez J. (2008) Effect of Biodiesel Fuels on Diesel Engine Emissions, Progress in Energy and Combustion Science, Vol. 34, 198-223.

[13] Kent Hoekman S. and Robbins C. (2012) Review of the effects of biodiesel on NOx emissions, Fuel Processing Technology, Vol. 96, 237-249.

[14] Varatharajan K. and Cheralathan M. (2012) Influence of fuel properties and composition on NOx emissions from biodiesel, Renewable and Sustainable Energy Reviews, Vol. 16, 3702-3710.

[15] Pandey R., Rehman A. and Sarviya R. (2012) Impact of Alternative Fuel Properties on Fuel Spray Behavior and Atomization, Renewable and Sustainable Energy Reviews, Vol. 16, 1762-1778.

[16] Monyem A., Van Gerpen J. H. and Canakci M. (2001) The Effect of Timing and Oxidation on Emissions from Biodiesel-Fuelled Engines, American Society of Agricultural Engineers, Vol. 44, 35-42. 
[17] Barabas I., Todorut A. and Baldean D. (2010) Performace and Emission Characteristics of an CI Engine Fuelled with Diesel-Biodiesel-Bioethanol Blends, Fuel, Vol. 89, 3827-3832.

[18] Knothe G., Sharp C. A. and Ryan III T.W. (2006) Exhaust Emissions of Biodiesel, Petrodiesel, Neat Methyl Esters, and Alkanes in a New Technology Engine, Energy Fuels, Vol. 20, 403-408.

[19] Yuan W., Hansen A. C., Tat M. E., Van Gerpen J.H. and Tan Z. (2005) Spray, Ignition and Combustion Modeling of Biodiesel Fuels for Investigating NOx Emissions, American Society of Agricultural Engineers, Vol. 48, No. 3, 933-939.

[20] Ndana M., Grace J. J., Baba F. H. and Mohammed U. M. (2013) Fourier Transform Infrared Spectrophotometric Ana;ysis of Functional Groups in Biodiesel Produced from Oils of Ricinus Communis, Hevea Brasiliensis and Jatropha Curcas Seeds, International Journal of Science, Environment and Technology, Vol. 2, No. 6, 1116-1121.

[21] Giakoumis E. G. (2012) A Statistical Investigation of Biodiesel Physical and Chemical Properties, and Their Correlation with the Degree of Unsaturation, Renewable Energy, Vol. 50, 858-878.

[22] Younis M. N., Saeed M.S. Khan S. Furqan M.U. Khan R.U. and Saleem M. (2009) Production and Characterization of Biodiesel from Waste and Vegetable Oils, Journal of Quality and Technology Management, Vol. 50, No. 1, 111-121. 


\section{Authors}

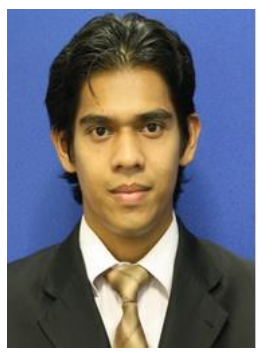

\section{Mohd Fareez Edzuan Bin Abdullah}

Mohd Fareez Edzuan Bin Abdullah is a lecturer, attached to the Department of Mechanical \& Manufacturing Engineering, Faculty of Engineering, Universiti Malaysia Sarawak (UNIMAS). His field of interest is internal engine combustion and renewable energy.

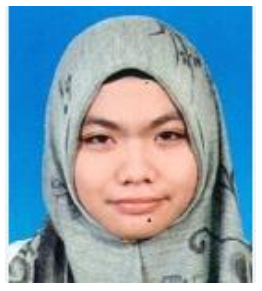

\section{Nadzirah Binti Madzrol}

Nadzirah Binti Madzrol is an under graduate engineering student at the Universiti Malaysia Sarawak (UNIMAS). She is expected to received her BEng (Hons) (Mechanical and Manufacturing Engineering) in 2015.

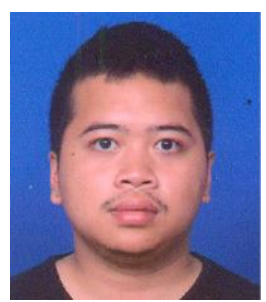

\section{Rolf Willa Anal Patrick Sandin}

Rolf Willa Anal Patrick Sandin is an under graduate engineering student at the Universiti Malaysia Sarawak (UNIMAS). He is expected to received his BEng (Hons) (Mechanical and Manufacturing Engineering) in 2015. 